\title{
ANALISIS MATERI TATA BAHASA PADA BUKU SEKOLAH ELEKTRONIK (BSE) JENJANG SEKOLAH MENENGAH PERTAMA
}

\author{
Alyvia Ananda \\ Dinas Pendidikan Pemuda dan Olahraga Kab. Sumbawa Barat \\ email: aleevya.sojunghan@gmail.com
}

\begin{abstract}
ABSTRAK
Penelitian ini bertujuan untuk mengungkapkan model penyampaian materi tata bahasa, cakupan materi tata bahasa, dan kesesuaian materi tata bahasa dengan Kurikulum 2006 (KTSP) pada BSE bahasa Indonesia jenjang sekolah menengah pertama (SMP). Penelitian ini merupakan penelitian deskriptif kualitatif. Sumber data dalam penelitian ini adalah buku sekolah elektronik mata pelajaran bahasa Indonesia. Data diperoleh melalui teknik membaca dan mencatat, dan dianalisis menggunakan teknik analisis konten. Hasil penelitian ini adalah sebagai berikut. Pertama, model penyampaian materi tata bahasa dalam BSE bahasa Indonesia terdiri atas dua, yaitu pendekatan deduktif dan induktif. Pendekatan deduktif digunakan pada materi fonologi, morfologi, sintaksis, dan semantik. Pendekatan induktif digunakan pada materi morfologi, sintaksis, dan semantik. Kedua, cakupan materi tata bahasa yang terdapat pada buku sekolah elektronik bahasa Indonesia jenjang SMP/MTs terdiri atas materi fonologi, morfologi, sintaksis, dan semantik. Materi fonologi hanya terdiri atas satu submateri, yaitu lafal dan diftong. Morfologi dibagi menjadi lima submateri, yaitu afiksasi, reduplikasi, kata tugas, kelas kata, dan penggunaan kata. Sintaksis dibagi menjadi tiga submateri, yaitu klausa, kalimat, dan fungsi SPOKPel. Semantik dibagi menjadi dua submateri, yaitu jenis-jenis semantik dan perubahan dan pergeseran makna. Ketiga, materi fonologi, morfologi, sintaksis, dan semantik, pada Standar Kompetensi dan Kompetensi Dasar tertentu telah sesuai dengan Kurikulum KTSP.
\end{abstract}

Kata Kunci: buku ajar, buku sekolah elektronik (BSE), materi tata bahasa

\section{AN ANALYSIS OF GRAMMAR MATERIALS IN JUNIOR HIGH SCHOOL ELECTRONICS BOOKS (E-BOOKS)}

\begin{abstract}
This study aims to reveal the model of delivery of grammar materials, the scope of grammar materials, and the compatibility of grammar materials with Curriculum 2006 which known as KTSP in junior high school Bahasa Indonesia's e-books. This study was a descriptive qualitative research. The data source was junior high school Bahasa Indonesia's e-books. The data were obtained through reading and noting technique, and analysed using the content analysis. The result of this study is as follows. First, there are two models of delivery of grammar materials used in Bahasa Indonesia's e-books. They are deductive and inductive approaches. The deductive approach is used in the delivery of phonology, morphology, syntax, and semantic materials. The inductive approach is used in the delivery of morphology, syntax, and semantic materials. Second, the grammar materials in junior high school Bahasa Indonesia's e-books consist of phonology, morphology, syntax, and semantic materials. Phonology materials consist of only one submaterial pronunciation and diphthong. Morphology materials consist of five submaterials: affixation, reduplication, said task, class word, and use of the word. Syntax materials consist of three submaterials: clause, sentence, and function of subject, predicate, object. Semantic materials consist of two submaterials including semantic and meaning changes. Third, phonology, morphology, syntax, and semantic materials integrated in certain competency standards and primary competency are compatible with KTSP Curriculum.
\end{abstract}

Keywords: textbook, e-books, grammar materials 


\section{PENDAHULUAN}

Pembelajaran bahasa Indonesia tidak bisa dipungkiri memiliki kedudukan penting dalam ranah pendidikan di Indonesia. Hal ini terbukti dengan dijadikan mata pelajaran Bahasa Indonesia sebagai mata pelajaran wajib mulai dari jenjang pendidikan dasar hingga perguruan tinggi. Pembelajaran bahasa Indonesia diharapkan dapat membantu membentuk peserta didik yang mampu berkomunikasi dengan baik di dalam masyarakat, mencintai bahasa dan budayanya, dan menggunakan serta meningkatkan kemampuan analisis dan imajinatif.

Tujuan pembelajaran bahasa Indonesia di atas dapat dicapai dengan memerhatikan empat keterampilan berbahasa, yaitu mendengarkan atau menyimak, berbicara, membaca, dan menulis. Untuk menunjang ketercapaian empat keterampilan berbahasa tersebut, dibutuhkan sumber pembelajaran seperti buku teks pelajaran. Keberadaan buku teks pelajaran sangat diperlukan. Buku teks pelajaran, dalam hal ini buku pelajaran bahasa Indonesia memuat materi-materi pembelajaran yang diturunkan dari Standar Kompetensi (SK) dan Kompetensi Dasar (KD) yang tercantum dalam kurikulum yang berlaku dan berfungsi untuk mengarahkan dan memudahkan proses pembelajaran. Awalnya, buku pelajaran hanya berupa buku cetak yang dihasilkan oleh para penulis dari berbagai penerbit. Namun, seiring perkembangan teknologi pada saat ini muncul dan dikenal istilah BSE atau Buku Sekolah Elektronik, yaitu buku pelajaran dengan format e-book. Buku Sekolah Elektronik ini mulai diluncurkan pemerintah pada tahun 2008 dan masih diproduksi hingga saat ini. Produksi BSE ini bertujuan agar setiap peserta didik memiliki akses cepat dan murah untuk memiliki buku pelajaran yang berkualitas dan telah teruji kelayakannya oleh Badan Standar nasional Pendidikan (BSNP).

Buku teks pelajaran ataupun BSE memuat materi-materi yang terdiri atas tiga aspek, yaitu berbahasa, bersastra, dan tata bahasa. Materi tata bahasa hadir dalam BSE bahasa Indonesia sebagai penyemperpuna pemerian materi kebahasaan dan kesastraan dan sebagai bentuk usaha dalam mengurangi kesalahan penggunaan bahasa yang masih banyak terjadi. Hal ini ditandai dengan adanya penelitian-penelitian tentang analisis kesalahan berbahasa dan tata bahasa hingga saat ini.

Sudarsono menyatakan pada dasarnya tata bahasa merupakan rambu-rambu yang harus dipatuhi oleh pemakai bahasa agar prilaku berbahasa mereka tetap memperlihatkan ciri kerapian dan kecermatan (Alwi, Dardjowidjojo, Lapoliwa, dan Moeliono, 2003). Selain itu, tata bahasa juga merupakan faktor penting untuk membangun kompetensi berbahasa siswa secara bertahap seperti yang dikemukakan oleh Sams (2003: 8) dalam jurnalnya, yaitu "we need to implement a sequenced approach to grammar instruction that is designed to build students' competence gradually". Materi tata bahasa yang disajikan tentunya berdasar kepada kurikulum yang digunakan sekarang, yaitu Kurikulum Tingkat Satuan Pendidikan (KTSP) 2006. Kurikulum harus berjenjang yang berarti materi pembelajaran dalam hal ini materi tata bahasa pada Sekolah Menengah Pertama merupakan kelanjutan dari materi Sekolah Dasar. Materi pembelajaran harus sesuai dengan $\mathrm{SK} / \mathrm{KD}$, indikator, dan tujuan pembelajaran sehingga materi tata bahasa yang diajarkan pada tingkat Sekolah Menengah Pertama tidak hanya mengulang materi di SD, melainkan melanjutkan dengan materi-materi yang baru sebagai penguat materi yang sebelumnya.

Materi tata bahasa merupakan pengetahuan dasar yang dijadikan fondasi bagi pembelajaran bahasa yang benar. Seperti yang diutarakan Cox (1998: 387) Teaching grammar is viewed as a basic skill. Dan grammar provides a foundation for learning correct language usage and writing, which are vital to success in school and the world. Penjabaran materi tata bahasa dalam buku pelajaran maupun Buku Sekolah Elektronik (BSE) meliputi ruang lingkup fonologi (tata bunyi), morfologi (tata bentuk), sintaksis (tata kalimat), dan semantik (tata makna). Penjabaran mengenai tata bahasa tersebut menimbulkan pertanyaan-pertanyaan mendasar seperti bagaimana penyajian materi tata bahasa dalam buku pelajaran? Apakah sudah ada pembagian materi tata bahasa di masing-masing jenjang atau kelas? Bagaimana keterkaitan antara materi tata bahasa dengan kurikulum? Hal-hal tersebut perlu diketahui, terutama materi tata bahasa dalam BSE mata 
pelajaran bahasa Indonesia, sehingga materi tata bahasa dapat disampaikan secara lebih efektif dalam pembelajaran di kelas.

Dalam penelitian ini, akan dibahas segala sesuatu tentang materi tata bahasa pada Buku Sekolah Elektronik (BSE). Masingmasing BSE memiliki model penyampaian yang berbeda. Untuk itu pada penelitian ini, peneliti akan membahas penyajian materi tata bahasa pada tiap-tiap BSE, cakupan materi tata bahasa pada BSE, dan kesesuaian materi tata bahasa dengan kurikulum KTSP pada BSE jenjang Sekolah Menengah Pertama (SMP) atau sederajat. Masing-masing BSE akan dianalisis dengan cara mendeskripsikan hasil temuan yang berkenaan dengan materi tata bahasa. Penelitian ini bertujuan untuk mengungkapkan model penyampaian materi tata bahasa, cakupan materi tata bahasa, dan kesesuaian materi tata bahasa dengan Kurikulum 2006 (KTSP) pada BSE bahasa Indonesia jenjang sekolah menengah pertama (SMP).

\section{METODE}

Penelitian analisis materi tata bahasa dalam Buku Sekolah Elektronik (BSE) ini merupakan jenis penelitian deskriptif dan menggunakan pendekatan kualitatif.

Penelitian ini merupakan jenis penelitian pustaka sehingga dalam pengkajiannya tidak dibatasi oleh lokasi tertentu. Waktu penelitian diperkirakan sekitar bulan Januari- Maret 2016.

Sumber data dalam penelitian ini adalah buku mata pelajaran Bahasa Indonesia jenjang Sekolah Menengah Pertama (SMP) yang disajikan dalam format Buku Sekolah Elektronik (BSE) dan dapat diakses di http://bse. kemdikbud.go.id.. BSE mata pelajaran Bahasa Indonesia yang digunakan adalah sebanyak 15 buku dengan rincian, kelas VII diambil 5 buku, kelas VIII diambil 5 buku, dan kelas IX sebanyak 5 buku.

Teknik pengumpulan data yang digunakan dalam penelitian ini adalah baca dan catat. Teknik baca dan catat, yaitu membaca secara cermat materi-materi tata bahasa yang ada dalam BSE mata pelajaran Bahasa Indonesia SMP atau sederajat yang kemudian dicatat dan dimasukkan ke dalam kartu data.
Teknik baca dan catat BSE untuk mendapatkan data membutuhkan instrumen berupa parameter. Parameter berfungsi untuk menentukan data materi tata bahasa dan model penyampaiannya.

Pada penelitian ini, analisis dilakukan secara kualitatif dengan cara mendeskripsikan hasil temuan sehingga mencapai kesimpulan. Pertama, data yang diperoleh dimasukkan ke dalam kartu data dan diberikan kode (coding). Kedua, data dianalisis berdasarkan fokus penelitian yang meliputi bagaimana model penyampaian materi tata bahasa disajikan, cakupan materi tata bahasa apa saja yang ada dalam masing-masing BSE mata pelajaran Bahasa Indonesia, dan kesesuaian antara materi tata bahasa dengan kurikuluum KTSP. Analisis ini berhubungan dengan proses identifikasi dan penampilan pola-pola yang penting. Hasil penelitian kemudian disajikan dalam bentuk tabel.

Keabsahan data diperoleh dengan teknik triangulasi. Triangulasi diperkenalkan secara luas oleh Denzin (Jick 1979: 602) sebagai "the combination of methodologies in the study of the same phenomenon". Penelitian ini menggunakan triangulasi data dan teori, karena menggunakan berbagai sumber data dan berbagai teori, perspektif atau sudut pandang untuk menginterpretasi hasil penelitian.

\section{HASIL DAN PEMBAHASAN}

Model Penyampaian Materi Tata Bahasa dalam BSE Mata Pelajaran Bahasa Indonesia Jenjang SMP/MTs

Dalam Buku Sekolah Elektronik (BSE) terdapat dua model penyampaian materi tata bahasa, yaitu melalui pendekatan deduktif dan pendekatan induktif. Model pendekatan deduktif merupakan model penyampaian materi yang diawali oleh penjelasan kaidah atau definisi yang bersifar umum kemudian disertai contohcontoh yang bersifat khusus. Model pendekatan induktif merupakan model penyampaian materi yang diawali contoh-contoh kemudian disertai penjelasan kaidah atau definisi umum.

Berdasarkan penelitian yang telah dilakukan, ditemukan bahwa model penyampaian materi tata bahasa dengan menggunakan pendekatan induktif lebih banyak digunakan, yaitu sebanyak 93 materi dibandingkan pendeka- 
tan deduktif yang berjumlah 56 materi tata bahasa. Pendekatan deduktif digunakan pada semua materi tata bahasa, sedangkan dalam pendekatan induktif digunakan pada materi morfologi, sintaksis, dan semantik (kecuali fonologi). Pada BSE kelas VII, total pendekatan deduktif digunakan pada 26 materi dan pendekatan induktif digunakan pada 23 materi. Pada BSE kelas VIII, pendekatan deduktif digunakan pada 10 materi dan pendekatan induktif sebanyak 43 materi.

Pada BSE kelas IX pendekatan ddeduktif digunakan pada 20 materi dan pendekatan induktif digunakan pada 27 materi.

Sebagai tingkatan awal pada jenjang SMP, BSE kelas VII lebih banyak memaparkan materi dengan menggunakan pendekatan deduktif. Hal ini bertujuan agar siswa pada tingkatan awal dapat dibekali terlebih dahulu dengan pengetahuan-pengetahuan yang bersifat umum (definisi umum) sebagai dasar untuk melanjutkan pembelajaran pada tingkat selanjutnya.

Jika pada kelas VII siswa dibekali dengan pengetahuan umum, pada kelas VIII siswa diberikan lebih banyak contoh-contoh konkret terelebih dahulu yang dapat membantunya untuk menarik kesimpulan umum atas contoh-contoh yang diberikan. Singkatnya, pendekatan induktif yang diterapkan pada kelas VIII bertujuan agar siswa dapat menerapkan, mensintesiskan, dan menemukan contoh konkret dari bekal pengetahuan atau kaidah umum yang diberikan pada kelas VII sebelumnya. Selanjutnya, pada BSE kelas IX, persebaran penggunaan pendekatan deduktif dan dan induktif hampir merata. Pada tingkat ini, siswa diharapkan tetap memegang dan memahami segala bentuk pengetahuan, terminologi, dan kaidah umum materi pembelajaran serta dapat terus mengaplikasikannya pada contoh-conth konkret. Pengetahuan umum dan pengaplikasian nyata dari materi-materi yang diberikan dapat benar-benar dikuasai siswa. Hasil analisis model penyampaian materi tata bahasa dalam BSE secara ringkas dapat dilihat pada tabel 1 .

Kesesuaian antara Materi Tata Bahasa dalam BSE dengan Kurikulum 2006 (KTSP) Mata Pelajaran Bahasa Indonesia Jenjang SMP/MTs

Kesesuaian materi tata bahasa dalam BSE dengan kurikulum KTSP dilihat dari penjabaran standar kompetensi-kompetensi dasar di dalam BSE. Berdasarkan kemunculannya materi tata bahasa dapat terintegrasi dengan kurikulum KTSP, yaitu pada materi fonologi, morfologi, sintaksis, dan semantik. Namun, berdasarkan data hasil temuan di atas, tidak ditemukan buku yang mencakup semua materi tata bahasa yang dapat masuk ke kurikulum (sesuai Standar Kompetensi-Kompetensi Dasar). Pada buku dengan kode VII.05 merupakan buku yang mencakup keselurahan materi tata bahasa (fonologi, morfologi, sintaksis, semantik). Materi tata

Tabel 1.Model Penyampaian Materi Tata Bahasa dalam BSE Mata Pelajaran Bahasa Indonesia SMP/MTs

\begin{tabular}{|c|c|c|c|c|c|c|c|c|c|c|c|}
\hline \multirow{2}{*}{ No. } & \multirow{2}{*}{$\begin{array}{l}\text { Kode } \\
\text { Buku }\end{array}$} & \multicolumn{5}{|c|}{ Materi dengan Pendekatan Deduktif } & \multicolumn{5}{|c|}{ Materi dengan Pendekatan Induktif } \\
\hline & & FON & MOR & SIN & SEM & $\sum$ & FON & MOR & SIN & SEM & $\sum$ \\
\hline 1. & VII.01 & & 4 & 1 & & 5 & & 4 & & & 4 \\
\hline 2. & VII.02 & & 7 & 3 & 1 & 11 & & & & & 0 \\
\hline 3. & VII.03 & & 3 & & & 3 & & 2 & & 2 & 4 \\
\hline 4. & VII.04 & & 2 & 2 & & 4 & & 2 & & & 2 \\
\hline 5. & VII.05 & 1 & & 2 & & 3 & & 8 & 2 & 3 & 13 \\
\hline 6. & VIII.01 & & 1 & & & 1 & & 10 & 4 & 2 & 16 \\
\hline 7. & VIII.02 & & 3 & & & 3 & & 8 & 3 & & 11 \\
\hline 8. & VIII.03 & & 1 & & & 1 & & 2 & & 2 & 4 \\
\hline 9. & VIII.04 & & 3 & & & 3 & & 9 & 2 & 1 & 12 \\
\hline 10. & VIII.05 & & 1 & 1 & & 2 & & & & & 0 \\
\hline 11. & IX.01 & & 2 & 2 & 2 & 6 & & 3 & 2 & & 5 \\
\hline 12. & IX.02 & & 3 & 1 & & 4 & & 2 & 2 & & 4 \\
\hline 13. & IX.03 & & 1 & 3 & 1 & 5 & & 3 & 2 & & 5 \\
\hline 14. & IX.04 & & 1 & 1 & 1 & 3 & & 10 & 2 & 1 & 13 \\
\hline \multirow[t]{2}{*}{15.} & IX.05 & & & 2 & & 2 & & & & & 0 \\
\hline & Jumlah & 1 & 32 & 18 & 5 & 56 & 0 & 63 & 19 & 11 & 93 \\
\hline
\end{tabular}

Analisis Materi Tata Bahasa pada Buku Sekolah Elektronik (BSE) ... (Alyvia Ananda) 
bahasa dikatakan sesuai dengan kurikulum jika materi tata bahasa yang disajikan relevan dan telah mencakup tujuan pembelajaran yang ingin dicapai oleh Kurikulum, sedangkan materi tata bahasa dikatakan tidak sesuai jika tidak materi tata bahasa yang disajikan tidak relevan dan tidak mencakup tujuan pembelajaran yang ingin dicapai oleh Kurikulum.

Berikut data hasil temuan kesesuaian materi tata bahasa dengan kurikulum 2006 (KTSP) ditinjau dari kemunculan materi tata bahasa dalam buku BSE dapat dilihat pada tabel 2.

Model Penyampaian Materi Tata Bahasa dalam BSE Mata Pelajaran Bahasa Indonesia Jenjang SMP/MTs

Terdapat dua pendekatan yang digunakan dalam penyampaian materi tata bahasa di dalam buku teks, yaitu pendekatan deduktif dan pendekatan induktif. Pendekatan deduktif merupakan pendekatan yang dimulai dengan penjelasan secara teoritis, kemudian diikuti dengan contoh-contoh. Pendekatan induktif merupakan pendekatan yang dimulai dari contoh-contoh kemudian diikuti dengan penjelasan secara teoritis.

\section{Pendekatan Deduktif}

Pendekatan deduktif merupakan pendekatan yang berangkat dari sebuah pengetahuan yang bersifat umum menjadi khusus. Pendekatan deduktif ditandai dengan pemaparan konsep, definisi dan istilah-istilah pada bagian awal pembelajaran. Dalam proses pembelajaran di kelas, pendekatan deduktif menggunakan sistem hafalan. Penghafalan dan pemahaman kaidah tata bahasa menjadi poin inti pada pendekatan deduktif. Deduktif merupakan cara berpikir untuk penarikan kesimpulan yang bersifat khusus dari pernyataan yang bersifat umum. Pendekatan ini bertujuan untuk memudahkan siswa dalam memahami materi tata bahasa dan menarik kesimpulan yang tepat beradasarkan pemahaman kaidah umum tentang tata bahasa. Pendekatan deduktif dapat digunakan pada materi yang belum diketahui atau dikenal siswa (Yamin, 2008: 89) serta tepat digunakan dalam pembelajaran yang menitikberatkan pada pemahaman stuktur atau kaidah tata bahasa. Berdasarkan hasil temuan, pendekatan deduktif digunakan pada materi fonologi, morfologi, sintaksis, dan semantik.

\section{Fonologi}

Materi fonologi yang menggunakan model pendekatan deduktif muncul pada buku BSE kelas VII, yaitu pada submateri lafal dan

Tabel 2. Kesesuaian Materi Tata Bahasa dalam BSE Bahasa Indonesia dengan Kurikulum 2006 (KTSP)

\begin{tabular}{|c|c|c|c|c|c|c|c|c|c|}
\hline \multirow{3}{*}{ No. } & \multirow{3}{*}{$\begin{array}{l}\text { Kode } \\
\text { Buku }\end{array}$} & \multicolumn{8}{|c|}{ Kesesuaian Materi Tata Bahasa dengan Kurikulum } \\
\hline & & \multicolumn{2}{|c|}{ Fonologi } & \multicolumn{2}{|c|}{ Morfologi } & \multicolumn{2}{|c|}{ Sintaksis } & \multicolumn{2}{|c|}{ Semantik } \\
\hline & & Sesuai & Tidak & Sesuai & Tidak & Sesuai & Tidak & Sesuai & Tidak \\
\hline 1. & VII.01 & - & - & $\sqrt{ }$ & & & $\sqrt{ }$ & - & - \\
\hline 2. & VII.02 & - & - & $\sqrt{ }$ & & $\sqrt{ }$ & & $\sqrt{ }$ & \\
\hline 3. & VII.03 & - & - & $\sqrt{ }$ & & - & - & $\sqrt{ }$ & \\
\hline 4. & VII.04 & - & - & $\sqrt{ }$ & & $\sqrt{ }$ & & - & - \\
\hline 5. & VII.05 & $\sqrt{ }$ & & $\sqrt{ }$ & & $\sqrt{ }$ & & & $\sqrt{ }$ \\
\hline 6. & VIII.01 & - & - & $\sqrt{ }$ & & $\sqrt{ }$ & & & $\sqrt{ }$ \\
\hline 7. & VIII.02 & - & - & $\sqrt{ }$ & & $\sqrt{ }$ & & - & - \\
\hline 8. & VIII.03 & - & - & $\sqrt{ }$ & & - & - & & $\sqrt{ }$ \\
\hline 9. & VIII.04 & - & - & $\sqrt{ }$ & & & $\sqrt{ }$ & $\sqrt{ }$ & \\
\hline 10. & VIII.05 & - & - & $\sqrt{ }$ & & $\sqrt{ }$ & & - & - \\
\hline 11. & IX.01 & - & - & $\sqrt{ }$ & & $\sqrt{ }$ & & $\sqrt{ }$ & \\
\hline 12. & IX.02 & - & - & $\sqrt{ }$ & & $\sqrt{ }$ & & - & - \\
\hline 13. & IX.03 & - & - & $\sqrt{ }$ & & $\sqrt{ }$ & & $\sqrt{ }$ & \\
\hline 14. & IX.04 & - & - & $\sqrt{ }$ & & $\sqrt{ }$ & & & $\sqrt{ }$ \\
\hline 15. & IX.05 & - & - & - & - & $\sqrt{ }$ & & - & - \\
\hline
\end{tabular}


diftong. Berikut ini data pendekatan deduktif yang digunakan pada materi fonologi.

\section{(1) Lafal dan Diftong}

Lafal atau pengucapan bunyi dalam bahasa Indonesia terbagi atas vokal (vokal tunggal dan diftong) serta konsonan. Vokal yang diucapkan dalam suku kata hidup diucapkan dengan sempurna sedangkan vokal yang diucapkan dalam suku kata mati diucapkan dengan tak sempurna.

Perhatikan contoh berikut!

motto o pada to diucapkan sempurna

motor o pada tor diucapkan tidak sempurna

batu u pada tu diucapkan sempurna

batuk u pada tuk diucapkan tidak sempurna

Diftong adalah vokal rangkap yang pengucapannya bersamaan sehingga bunyinya menjadi tidak sempurna. Diftong dalam bahasa Indonesia terdiri atas: ai, au, dan oi.

Perhatikan contoh berikut!

$$
\begin{array}{ll}
\text { san - tai } & \text { (san - tei }) \\
\text { ba - lai } & (\text { ba }- \text { lei }) \\
\text { ker - bau } & (\text { ker }- \text { bou }) \\
\text { pi - sau } & \text { (pi - sou }) \\
\text { am - boi } & (\text { am }- \text { boy }) \\
\text { se - poi } & \text { (se - poy })
\end{array}
$$

Konsonan ada yang diucapkan sempurna dan ada yang tidak sempurna. Sebagian besar konsonan dalam bahasa Indonesia diucapkan sempurna. Beberapa konsonan seperti konsonan $b$, $\mathrm{k}$, dan $\mathrm{h}$ pada awal atau tengah kata diucapkan sempurna, tetapi apabila konsonan tersebut terdapat pada akhir suku atau akhir kata diucapkan tidak sempurna.

Perhatikan contoh berikut!

baru, kain, hasil

Bunyi $b, k$, h pada kata tersebut diucapkan sempurna

Sabtu, bapak, sawah

Bunyi b, k, h pada kata tersebut diucapkan tidak sempurna

$$
\text { VII.05/I/22/Fon }
$$

Data (1) merupakan materi fonologi yang disajikan dengan menggunakan pendekatan deduktif. Hal ini dibuktikan dengan model pemaparan yang didahului oleh penjelasan konsep-konsep umum lafal dan diftong, mulai dari pengertian hingga cara pengucapan masing- masing fonem. Kemudian, pada bagian akhir diikuti dengan contoh diftong untuk lebih memperjelas kaidah umum sebelumnya. Pendekatan deduktif digunakan pada materi ini karena materi fonologi belum banyak diketahui oleh siswa terutama pada jenjang SMP. Seperti yang telah dijelaskan sebelumnya, bahwa pendekatan deduktif dapat digunakan jika siswa belum mengenal materi tersebut. Materi lafal, vokal tunggal, dan konsonan mungkin tidak asing bagi siswa. Namun, vokal ganda atau diftong tentunya merupakan materi yang masih perlu penjelasan lebih lanjut bagi siswa pada tingkatan SMP. Berdasarkan hal tersebut diperlukan pemaparan mengenai terminologi atau kaidah umum tentang diftong. Penerapan pendekatan deduktif ini dapat membantu siswa untuk memeroleh pemahaman dasar tentang diftong sehingga siswa dapat mengaplikasikan pengetahuan tersebut ke dalam contoh-contoh konkret yang mungkin sebelumnya pernah dijumpai pada kegiatan berkomunikasi sehari-hari siswa.

Morfologi

Pendekatan deduktif digunakan pada materi morfologi pada buku BSE kelas VII, VIII, dan IX. Berikut ini data pendekatan deduktif yang digunakan pada materi morfologi (Reduplikasi).

(2) Kata Ulang

1. Pengertian

Kata ulang adalah kata yang terdiri dari perulangan kata dasar.

Contoh:

kata $\rightarrow$ kata-kata

gerak $\rightarrow$ gerak-gerik

senang $\rightarrow$ senang-senang

sayur $\rightarrow$ sayur-mayur

tiba $\rightarrow$ tiba-tiba

lauk $\rightarrow$ lauk-pauk

balik $\rightarrow$ bolak-balik

baik $\rightarrow$ baik-baik

2. Kata dasar kata ulang

a. Berdasarkan bentuknya

1) Kata asal, misalnya, takut-takut, tibatiba, makan-makan, bolak-balik, gerakgerik, dan sebagainya. 
2) Kata bersambungan, misalnya, makanan-makanan, berjalan-jalan, hulubalang-hulubalang, dan sebagainya.

b. Berdasarkan jenis katanya

1) Kata keadaan, misalnya, takut-takut, baik-baik,dan sebagainya.

2) Kata kerja, misalnya, makan-makan, minum-minum, tiba-tiba, dan sebagainya.

3) Kata benda, misalnya, hulubalanghulubalang, makanan-makanan, bajubaju, dan sebagainya.

4) Kata bilangan, misalnya, satu-satu, sepuluh-sepuluh,dan sebagainya.

5) Kata ganti, misalnya, apa-apa, siapasiapa,dan sebagainya.

VII.01/II/169-172/Mor

Data (2) merupakan materi morfologi yang disajikan dengan pendekatan deduktif yang dibuktikan dengan pemerian pengertian kata ulang, jenis-jenis pengulangan seperti pengulangan seluruh, pengulangan sebagian, pengulangan berimbuhan, dan pengulangan de-ngan perubahan dan arti atau makna yang muncul karena proses pengulangan atau reduplikasi pada bagian awal materi. Bagian akhir dipaparkan dengan contoh-contoh reduplikasi atau pengulangan. Pendekatan deduktif digunakan pada materi ini bertujuan untuk mempermudah siswa dalam memahami ragam jenis kata ulang yang terbagi berdasarkan bentuk dan jenis kata. Pemberian penjelasan umum tentang jenis-jenis kata ulang ini dapat membantu siswa untuk membedakan masing-masing jenis kata ulang dan menerapkannya dalam suatu kalimat yang tepat serta sebagai bekal dasar dalam pembelajaran selanjutnya.

\section{Sintaksis}

Pendekatan deduktif digunakan pada materi sintaksis pada buku BSE kelas VII, VIII, dan IX. Berikut ini data pendekatan deduktif yang digunakan pada materi sintaksis.
(3) Memahami dan Menggunakan Kalimat Majemuk

Kalimat majemuk setara adalah kalimat gabung yang hubungan antara pola-pola kalimat di dalamnya sederajat.

Jenis kalimat majemuk setara mencakup:

a. Kalimat majemuk setara hubungan penggabungan, yaitu rangkaian dua kalimat tunggal menggunakan kata tugas: dan, serta, lagi pula, dan sebagainya.

Contoh: Paman pergi ke kantor dan bibi pergi ke pasar.

b. Kalimat majemuk setara hubungan memilih, yaitu rangkaian kalimat dengan menggunakan kata tugas: atau, baik ... maupun, dan sebagainya.

Contoh: Kita tetap menjadi pekerja atau pencari uang demi keluarga.

c. Kalimat majemuk setara hubungan pertentangan, yaitu rangkaian dua kalimat dengan menggunakan kata tugas: tetapi, melainkan, sedangkan, padahal, dan sebagainya.

Contoh: Pemuda tadi rajin sebagai kuli, tetapi kakaknya pemalas.

IX.01/II/185/Sin

Data (3) merupakan materi sintaksis yang disajikan dengan pendekatan deduktif. Bagian awal materi memaparkan definisi kalimat majemuk setara yang merupakan kalimat gabung yang hubungan antara pola-pola kalimat di dalamnya sederajat. Kemudian kalimat majemuk setara dibagi menjadi beberapa jenis sambil disertakan dengan contoh-contohnya. Pemaparan secara deduktif ini bertujuan untuk membantu siswa untuk lebih memahami jenis-jenis kalimat majemuk setara yang terdiri atas empat jenis, yaitu kalimat majemuk setara hubungan penggabungan, kalimat majemuk setara hubungan memilih, kalimat majemuk setara hubungan pertentangan, dan kalimat majemuk setara hubungan sebab akibat. Keempat jenis kalimat majemuk setara tersebut menggunakan kata tugas yang berbeda-beda. Sehingga penguatan materi yang bersifat penjelasan umum kalimat majemuk setara akan membantu meminimalisir kesalahan penggunaannya dalam praktik berbahasa. Penggunaan pendekatan deduktif dapat membantu siswa untuk mampu memahami 
kaidah-kaidah dan jenis dari kalimat majemuk setara tersebut.

\section{Semantik}

Pendekatan deduktif digunakan pada materi semantik pada buku BSE kelas VII dan IX. Berikut ini data pendekatan deduktif yang digunakan pada materi sintaksis.

(4) Ameliorasi, Peyorasi, Generalisasi, dan Spesialisasi

Sebuah kata dalam bahasa Indonesia sangat mungkin mengalami dua jenis pergeseran makna. Pergeseran makna tersebut antara lain ameliorasi dan peyorasi serta generalisasi dan spesialisasi.

1. Ameliorasi

Ameliorasi adalah perubahan makna yang mengakibatkan makna sekarang lebih tinggi nilainya daripada makna dahulu.

Contoh:

Perempuan itu seniman Indonesia yang punya nama internasional.

Dahulu kata perempuan digunakan untuk menyebut wanita yang dianggap tidak baik perilakunya. Sekarang kata perempuan digunakan untuk menyebut wanita yang punya prestasi atau wanita yang punya perilaku baik.

2. Peyorasi

Peyorasi merupakan kebalikan dari ameliorasi. Peyorasi adalah perubahan makna yang mengakibatkan makna baru dirasakan lebih rendah daripada makna dahulu.

Contoh:

Bini pamanku berasal dari Palembang.

Kata bini dahulu untuk menyebut istri. Sekarang kata bini digunakan dengan makna yang lebih rendah dari kata istri atau nyonya.

3. Generalisasi

Generalisasi merupakan perluasan makna dari sebuah kata. Makna sekarang lebih luas daripada makna dahulu.

Contoh:

Siapa nama bapakyang berbaju batik itu? Dahulu kata bapak hanya berarti orang tua laki-laki. Sekarang kata bapak selain berarti orang tua laki-laki juga berarti orang yang dihormati atau pemuka masyarakat.

\section{Spesialisasi}

Spesialisasi atau penyempitan makna adalah kata yang saat ini artinya lebih sempit dari arti sebelumnya.

Contoh:

Pembantu di rumahku sedang pulang kampung.

Dahulu kata pembantu berarti orang yang memberi bantuan. Sekarang kata pembantu berarti pramuwisma atau orang yang bekerja sebagai pembantu rumah tangga.

IX.04/I/23-24/Sem

Data (4) merupakan materi semantik yang disajikan dengan pendekatan deduktif. Bagian awal materi memaaparkan mengenai pergeseran makna bahasa dalam bahasa Indonesia yang dilanjutkan dengan definisi umum dari masing-masing jenis pergeseran makna, yaitu ameliorasi, peyorasi, generalisasi, dan spesialisasi. Selanjutnya, untuk memperjelas definisi dari masing-masing jenis pergeseran makna disertakan contoh-contohnya. Pemberian definisi dan penjelasan umum tentang jenis pergeseran makna akan mempertajam pengetahuan siswa sebelum mempraktikkannya dalam praktik berbahasa yang sesungguhnya dan mengurangi terjadinya kesalahan penggunaan dalam keterampilan berbahasa baik dalam bentuk tulis maupun lisan.

Secara umum, pemaparan materi tata bahasa dalam BSE bahasa Indonesia SMP dengan pendekatan deduktif bertujuan untuk membekali dan menanamkan pengetahuan dan kaidah umum tentang suatu struktur bahasa secara langsung kepada siswa. Siswa juga diharapkan mampu memahami kaidah tersebut dengan mengulang aktivitas membaca untuk meningkatkan keterampilan berbahasa. Namun, jika diterapkan dalam pembelajaran di kelas, pendekatan deduktif lebih bersifat teacher-centered dan siswa menjadi pasif. Namun, dengan pemberian penjelasan tentang kaidah umum struktur bahasa yang tepat dan memadai, siswa menjadi terbekali dengan ilmu yang berguna untuk pengembangan kemampuan berbahasanya.

\section{Pendekatan Induktif}

Pendekatan induktif merupakan pendekatan yang berangkat dari sebuah penge- 
tahuan yang bersifat khusus menjadi umum. Pendekatan induktif ditandai dengan pemerian contoh-contoh pada bagian awal pembelajaran untuk menuju pada konsep, definisi dan istilahistilah. Pemaparan contoh-contoh pada awal pembelajaran bertujuan untuk merangsang siswa dalam mengingat kembali penggunaan struktur bahasa yang pernah digunakan dan diucapkan siswa dalam kegiatan sehari-hari. Hal ini dapat memudahkan siswa dalam memahami makna kata tersebut dan menggunakannya dengan baik dan benar. Pendekatan induktif tepat digunakan pada materi yang telah dikenal oleh siswa. Berdasarkan hasil temuan, pendekatan induktif digunakan pada materi morfologi, sintaksis, dan semantik.

\section{Morfologi}

Pendekatan induktif digunakan pada materi morfologi pada buku BSE kelas VII, VIII, dan IX. Berikut ini data pendekatan deduktif yang digunakan pada materi morfologi.

(5) Memahami dan Menggunakan Imbuhan ter-, ter-kan, ter-i

a. Memahami dan Menggunakan Awalan ter-

1) Buku Sinta terbawa oleh Sari

Arti imbuhan ter : menyatakan perbuatan yang tidak disengaja

2) Terdakwa perampokan itu telah ditangkap polisi

Arti imbuhan ter : menyatakan orang yang di ....

3) Tulisannya baik dan rapi sehingga terbaca dengan jelas oleh siapa pun

Arti imbuhan ter : dapat di .... (dibaca)

b. Memahami dan Menggunakan Awalan terkan

Perhatikan contoh berikut ini!

1) Acara yang bagus itu terlewatkan begitu saja.

Arti imbuhan ter-kan pada kata terlewatkan adalah tidak sengaja/tidak terasa dilewatkan.

2) Kebaikan-kebaikannya tak terlupakan sepanjang masa.

Arti imbuhan ter-kan pada kata terlupakan adalah tak dapat dilupakan.
3) Kesedihan hatinya tak terlukiskan dengan kata-kata.

Arti imbuhan ter-kan pada kata terlukiskan adalah tak dapat dilukiskan.

c. Memahami dan menggunakan Awalan ter-i

Perhatikan contoh berikut ini!

1) Mereka tidak merasa terbebani oleh tugas ini.

Arti imbuhan ter-i pada kata terbebani adalah mendapat beban.

2) Target itu telah terlampaui pada bulan kemarin.

Arti imbuhan ter-i pada kata terlampaui adalah dapat dilampaui

3) Pikiran anak-anak mulai teracuni tayangan-tayangan televisi yang kurang mendidik.

Arti imbuhan ter-i pada kata teracuni adalah dimasuki/dipengaruhi.

IX.01/I/114-115/Mor

Data (5) merupakan materi morfologi yang disajikan dengan pendekatan induktif. Hal ini dibuktikan dengan melihat pada bagian awal materi penulis langsung memberikan contoh-contoh dari pemakaian masing-masing imbuhan baik yang berupa prefiks ter- maupun konfiks ter-kan dan ter-i. Kemudian diikuti dengan penjelasan arti atau makna dari tiap-tiap kata yang mengalami proses afiksasi tersebut. Pada materi ini, siswa diharapkan mampu memahami tentang pembentukan kata baru serta arti atau makna dari kata yang terbentuk melalui proses afiksasi tersebut. Penggunaan pendekatan induktif pada materi ini dirasa tepat untuk mencapai tujuan pembelajaran tersebut. Pemberian contoh-contoh kata dalam kalimat yang secara alami pernah dialami atau terpikirkan oleh siswa membantu siswa untuk lebih memahami tujuan pembelajaran dan siswa mampu memahami kaidah umum mengenai afiksasi yang berupa prefiks ter- dan konfiks ter-kan dan ter-i dari praktik menulis kalimat dengan menggunakan kata-kata yang mengalami proses afiksasi tersebut.

Selain menggunakan pendekatan induktif, materi morfologi lainnya pada buku IX.01 juga menggunakan pendekatan deduktif seperti pada materi kata serapan dan reduplikasi. Pendekatan deduktif dapat digunakan pada ma- 
teri baru yang belum dikenal oleh siswa, sedangkan pendekatan induktif dapat digunakan pada materi yang telah dikenal oleh siswa. Pendekatan deduktif digunakan agar siswa dapat memahami sepenuhnya kaidah umum atau terminologi materi baru yang diberikan, sedangkan pendekatan induktif digunakan untuk merangsang siswa dalam mengingat kembali penggunaan struktur bahasa yang pernah digunakan dan diucapkan siswa dalam kegiatan sehari-hari.

\section{Sintaksis}

Pendekatan induktif digunakan pada materi sintaksis pada buku BSE kelas VII, VIII, dan IX. Berikut ini data pendekatan induktif yang digunakan pada materi sintaksis.

(6) Kalimat Majemuk Bertingkat

Perhatikan dengan saksama kalimat-kalimat berikut ini!

1. Ayah mengatakan bahwa hari ini paman akan pulang.

2. Ketika hujan turun, Ahmad baru pulang dari sekolah.

3. Lelaki yang berbaju merah itu kakak sepupuku.

Jika kamu perhatikan dengan saksama, kalimat (1), (2), dan (3) terdiri atas dua klausa yang yang memiliki hubungan tidak setara. Kalimat semacam itu disebut kalimat majemuk bertingkat. Dalam kalimat majemuk bertingkat terdapat klausa yang menjadi bagian dari klausa yang lain. Klausa yang menjadi bagian dari klausa utama disebut anak kalimat atau klausa sematan, sedangkan klausa utama disebut klausa atasan atau induk kalimat. Sekarang, buatlah tiga kalimat majemuk bertingkat dengan menggunakan konjungsi yang, bahwa, dan ketika!

VIII.04/II/158/Sin

Data (6) merupakan materi kalimat majemuk bertingkat yang disajikan dengan pendekatan induktif. Bagian awal materi memaparkan contoh-contoh kalimat majemuk bertingkat. Kemudian, dilanjutkan dengan pemaparan definisi dan konsep-konsep kalimat majemuk bertingkat. Disebutkan bahwa kalimat majemuk bertingkat terdiri dari dua klausa (atasan dan sematan) yang memiliki hubungan tidak setara. Seperti yang dijelaskan sebelumnya di atas, bahwa pendekatan induktif tepat digunakan pada materi yang telah diketahui atau dikenal oleh siswa. Penggunaan pendekatan induktif dalam materi ini bertujuan membantu siswa untuk lebih mudah memahami makna kalimat yang terbentuk dalam kalimat majemuk bertingkat serta memahami dan mengingat kembali konsep atau kaidah kalimat majemuk bertingkat yang pernah diajarkan pada kelas VII. Peran aktif siswa dalam mengingat penggunaan kalimat majemuk bertingkat yang pernah digunakan, dapat mempermudah siswa dalam memahami makna kalimat tersebut. Pemerian contoh di awal materi dengan kata hubung yang ditulis miring juga akan langsung memberikan pemahaman umum ke siswa bahwa kalimat majemuk bertingkat ditandai dengan adanya penggunaan tanda hubung, seperti bahwa, ketika, dan yang. Pada buku yang sama materi sintaksis tentang kalimat majemuk setara juga disajikan dengan pendekatan induktif. Pendekatan induktif digunakan untuk materi yang telah dikenal oleh siswa dan bertujuan membantu siswa untuk lebih mudah memahami makna kalimat yang terbentuk dalam kalimat majemuk setara.

\section{Semantik}

Pendekatan induktif digunakan pada materi semantik pada buku BSE kelas VII, VIII, dan IX. Berikut ini data pendekatan induktif yang digunakan pada materi semantik.

(7) Menentukan Sinonim, Antonim, dan Polisemi

a. Sinonim

Perhatikan kalimat berikut ini!

Bencana alam seperti banjir, gunung meletus, angin topan, dan sebagainya merupakan suatu peristiwa yang tak dapat diduga, setiap saat dapat terjadi. Kata bercetak miring dalam kalimat di atas memiliki arti sama dengan kata-kata berikut:

bencana $=$ musibah

angin topan $=$ badai

peristiwa $=$ kejadian

Kata-kata yang memiliki makna sama seperti itu disebut sinonim. Sinonim adalah dua kata atau lebih yang memiliki makna sama atau hampir sama. Sinonim sebuah 
kata dapat ditentukan dari konteks kalimatnya.

b. Antonim

Perhatikan kalimat berikut ini!

Awan panas yang dikeluarkan gunung Merapi prosesnya terlalu cepat. Kata bercetak miring dalam kalimat di atas artinya berlawanan dengan kata-kata berikut:

panas $><$ dingin

Kata-kata yang memiliki arti berlawanan seperti itu disebut antonim. Antonim adalah kata yang mempunyai makna kebalikan atau berlawanan dari makna kata yang lain.

c. Polisemi

Perhatikan contoh-contoh berikut ini!

a. Kepala adikku terbentur dinding. Kepala = bagian tubuh paling atas

b. Kepala kereta api baru saja dilepas dari gerbong penumpang.

Kepala kereta api $=$ lokomotif

c. Kepala stasiun sibuk sekali.

Kepala stasiun = pimpinan stasiun

Kata kepala dalam contoh-contoh tersebut memiliki hubungan makna. Makna dasar dari ketiga kata itu sama, yaitu sesuatu yang kedudukannya berada di atas.

VII.03/I/4-6/Sem

Data (7) merupakan materi semantik yang disajikan dengan pendekatan induktif. Hal ini dibuktikan dengan bagian awal dipaparkan contoh-contoh dari masing-masing jenis relasi makna yaitu, sinonim, antonim, dan polisemi. Kemudian, dilanjutkan dengan pemaparan definisi dan konsep-konsep sinonim, antonim, dan polisemi untuk lebih memperjelas contoh-contoh yang telah diberikan di awal. Pemberian contoh penggunaan kata bersinonim dan berantonim dalam kalimat berita akan membantu siswa memahami makna kata-kata tersebut dengan mudah. Siswa dapat menghubungkan makna kata yang ditemukan pada kalimat dengan kata-kata yang pernah dijumpai sebelumnya. Misalnya, pada contoh 'Bencana alam seperti banjir, gunung meletus, angin topan, dan sebagainya merupakan suatu peristiwa yang tak dapat diduga, setiap saat dapat terjadi' siswa dapat menentukan sinonim kata 'bencana' dengan melihat kata-kata setelahnya, yaitu banjir, gunung meletus, dan angin topan. Pendekatan induktif cocok digunakan pada jenis materi semantik karena, pendekatan induktif lebih memokuskan dalam memahami makna kata dalam kalimat. Dengan menggunakan pendekatan induktif, siswa menjadi aktif mencari padanan kata yang bersinonim, berantonim, dan berpolisemi serta memahami makna kata dalam kalimat dan dapat langsung mempraktikkan dalam menulis kalimat berita. Pada buku yang sama materi semantik tentang makna konotasi dan denotasi disajikan dengan pendekatan induktif. Pada buku berbeda, yaitu IX.01 materi semantik tentang jenis pergeseran makna disajikan dengan pendekatan deduktif. Penggunaan pendekatan deduktif pada materi ini bertujuan agar siswa mampu memahami terminologi dan definisi yang bersifat umum dari jenis-jenis pergeseran makna.

Secara umum, pendekatan induktif dapat membantu siswa lebih berperan aktif dan produktif memahami kaidah tata bahasa suatu bahasa tertentu saat menggunakan bahasa tersebut. Pemilihan penggunaan pendekatan deduktif dan induktif didasari pada baru atau tidaknya materi yang diajar dan waktu pembelajaran yang tersedia. Pendekatan deduktif digunakan pada materi baru yang belum dikenal oleh siswa, lebih menekankan pada pembelajaran tentang terminologi yang bersifat umum, dan waktu pempembelajaran sedikit. Pendekatan induktif digunakan pada materi yang telah dikenal oleh siswa, lebih menekankan pada pembelajaran makna, dan waktu pembelajaran yang panjang.

Kesesuaian antara Materi Tata Bahasa dalam BSE dengan Kurikulum 2006 (KTSP) Mata Pelajaran Bahasa Indonesia Jenjang SMP/MTs

Dari sebanyak 162 materi tata bahasa yang ditemukan dalam BSE bahasa Indonesia jenjang Sekolah Menengah Pertama tidak semua yang sesuai dengan kurikulum KTSP. Total sebanyak 88 materi tata bahasa yang sesuai dengan kurikulum KTSP. Dalam menilai kesesuaian materi tata bahasa dengan kurikulum KTSP ada dua hal yang harus diperhatikan, yaitu keluasan materi dan kedalaman materi. Keluasan materi yang dimaksudkan adalah materi mencerminkan jabaran yang mendukung pencapaian Kompe- 
tensi Dasar (KD) dan pengembangan materi secara proporsional. Kedalaman materi mencakup tingkat kesulitan konsep sesuai dengan perkembangan peserta didik. Berikut ini adalah pembahasan tentang kesesuaian materi tata bahasa dengan kurikulum KTSP berdasarkan Standar Kompetensi-Kompetensi Dasar (SK$\mathrm{KD})$ yang ada.

\section{Fonologi}

Materi fonologi yang sesuai dengan kurikulum muncul pada BSE kelas VII dengan kode 05 , yaitu pada keterampilan membaca KD 3.3 Membacakan berbagai teks perangkat upacara dengan intonasi yang tepat. Berikut data materi fonologi yang sesuai dengan kurikulum.

\section{(8) Lafal dan Diftong}

Lafal atau pengucapan bunyi dalam bahasa Indonesia terbagi atas vokal (vokal tunggal dan diftong) serta konsonan. Vokal yang diucapkan dalam suku kata hidup diucapkan dengan sempurna sedangkan vokal yang diucapkan dalam suku kata mati diucapkan dengan tak sempurna.

Perhatikan contoh berikut!

motto o pada to diucapkan sempurna

motor o pada tor diucapkan tidak sempurna

batu u pada tu diucapkan sempurna

batuk u pada tuk diucapkan tidak sempurna VII.05/I/22/Fon

\section{(9) Diftong}

Diftong adalah vokal rangkap yang pengucapannya bersamaan sehingga bunyinya menjadi tidak sempurna. Diftong dalam bahasa Indonesia terdiri atas: ai, au, dan oi.

Perhatikan contoh berikut!

$$
\begin{array}{ll}
\text { san - tai } & \text { (san - tei }) \\
\text { ba - lai } & (\text { ba }- \text { lei }) \\
\text { ker - bau } & (\text { ker }- \text { bou }) \\
\text { pi - sau } & \text { (pi - sou }) \\
\text { am - boi } & (\text { am }- \text { boy }) \\
\text { se - poi } & \text { (se - poy })
\end{array}
$$

Konsonan ada yang diucapkan sempurna dan ada yang tidak sempurna. Sebagian besar konsonan dalam bahasa Indonesia diucapkan sempurna. Beberapa konsonan seperti konsonan $b$, $\mathrm{k}$, dan $\mathrm{h}$ pada awal atau tengah kata diucapkan sempurna, tetapi apabila konsonan tersebut terdapat pada akhir suku atau akhir kata diucapkan tidak sempurna.

Perhatikan contoh berikut!

baru, kain, hasil

Bunyi b, k, h pada kata tersebut diucapkan sempurna

Sabtu, bapak, sawah

Bunyi b, k, h pada kata tersebut diucapkan tidak sempurna

VII.05/I/22/Fon

Materi fonologi memang tidak banyak muncul pada BSE SMP tetapi bukan berarti tidak muncul sama sekali. Data (8) dan (9) menunjukkan bahwa BSE bahasa Indonesia kelas VII memiliki materi khusus fonologi yaitu tentang lafal dan diftong. Materi ini masuk pada keterampilan membaca dengan Standar Kompetensi (SK) Memahami ragam teks nonsastra dengan berbagai cara membaca. Dilihat dari segi keluasan materi, materi yang dipaparkan telah sesuai dan mencerminkan tujuan $\mathrm{KD}$ yaitu Mampu membacakan berbagai teks perangkat upacara secara tepat yang membutuhkan ketepatan pengucapan atau pelafalan bunyi bahasa. Pengembangan materi dan tingkat kesulitan materi sesuai dengan perkembangan pengetahuan peserta didik yang perlu diajarkan mulai dari konsep bahasa yang paling sederhana.

\section{Morfologi}

Materi morfologi yang sesuai dengan kurikulum terdapat pada KD 4.3 Menulis teks pengumuman dengan bahasa yang efektif, baik, dan benar kelas VII semester I. Berikut contoh materi afiksasi yang sesuai dengan kurikulum KTSP.

(10) Menggunakan Imbuhan per-, pe-, dan pean.

Awalan per-. Perhatikan nosi kata berawalan per- berikut ini!

1. Para petani menggunakan urea tablet. Petani $=$ orang yang pekerjaannya bertani

2. Ayam petelur mulai dibudidayakan di desadesa.

Petelur = yang menghasilkan telur

3. Perbesar tempat penampungan sampah itu. Perbesar $=$ membuat jadi lebih besar 
Imbuhan pe-

Imbuhan pe- mempunyai variasi bentuk atau alomorf pem-, peny-, pen, pel- dan penga.

Fungsi imbuhan pe-

Contoh:

1) buru (KK) pemburu (KB)

2) takut $(\mathrm{KS})$ penakut $(\mathrm{KB})$

Imbuhan pe-an

Imbuhan pe-an memiliki variasi bentuk atau alomorf pem-an, peny-an, peng-an, pel-an, dan pen-an.

a. Fungsi imbuhan pe-an

Membentuk kata benda

Contoh :

1) mandi (KK) $\rightarrow$ pemandian (KB)

2) lihat $(\mathrm{KK}) \rightarrow$ penglihatan $(\mathrm{KB})$

b. Makna imbuhan pe-an

1) Menyatakan tempat

Contoh :

a) Ayahnya bekerja di pengadilan.

b) Pelelangan itu banyak dikunjungi orang.

VII.03/II/102-103/Mor

Data (10) merupakan data materi morfologi yang sesuai dengan kurikulum KTSP pada $\mathrm{KD}$ Menulis teks pengumuman dengan bahasa yang efektif, baik, dan benar. KD tersebut masuk pada keterampilan menulis dan Standar Kompetensi (SK) Mengungkapkan pikiran dan pengalaman dalam buku harian dan surat pribadi yang menuntut siswa untuk mampu menulis teks pengumuman dengan bahasa yang efektif, baik, dan benar. Materi afiksasi tentunya dapat masuk ke dalam pembahasan karena dalam penciptaan kata atau kalimat tentunya tidak lepas dari proses afiksasi yang dalam materi ini berupa prefiks per-, pe-, dan konfiks pe-an. Materi di atas telah sesuai dan mencerminkan tujuan yang ingin dicapai dalam pemebelajaran yang mengacu pada kompetensi dasar.

\section{Sintaksis}

Materi sintaksis yang sesuai dengan kurikulum terdapat pada KD 2.1 Mengkritik/ memuji berbagai karya (seni atau produk) dengan bahasa yang lugas dan santun kelas IX semester I. Berikut contoh materi kalimat kritik dan kalimat pujian yang sesuai dengan kurikulum KTSP.

(11) Kalimat Kritikan dan Pujian

Mengkritik adalah memberikan tanggapan, kadang-kadang disertai dengan uraian dan pertimbangan baik buruk terhadap suatu hasil karya sastra, karya seni, atau pendapat. Kritikan yang baik disertai dengan alternatif untuk memperbaiki sesuatu yang dikritik. Kritikan muncul karena seseorang tidak setuju atau tidak suka akan sesuatu.

Contoh kalimat kritikan

1. Warna merah pada lukisan ini terlalu mencolok. Warna lain tidak kelihatan. Sebaiknya, warna merah dibuat agak tua.

Memuji atau memberikan pujian adalah melahirkan kekaguman dan penghargaan pada sesuatu yang dianggap baik, indah, gagah, berani, dan sebagainya. Memberikan kritik harus efektif, yaitu memberikan kritik kepada orang yang tepat dan benar-benar bisa diterima dan dilakukan oleh orang yang diberi kritik.

Contoh kalimat pujian

1. Lukisan ini benar-benar bagus. Binatang yang ada dalam lukisan ini seperti benarbenar hidup.

IX.04/I/14/Sin

Data (11) menunjukkan bahwa materi kalimat pujian dan kalimat kritikan sesuai dengan tujuan KD Mengkritik/memuji berbagai karya (seni atau produk) dengan bahasa yang lugas dan santun yang terdapat dalam SK berbicara tentang Mengungkapkan pikiran dan perasaan, dan informasi dalam bentuk komentar dan laporan. Materi kalimat pujian dan kritikan muncul secara menyatu untuk mencapai tujuan pembelajaran, yaitu siswa mampu mengkritik dan memuji dengan bahasa yang lugas dan santun.

Semantik

Materi semantik yang sesuai dengan kurikulum terdapat pada KD 4.2 Meresnsi buku pengetahuan kelas IX semester I. Berikut contoh materi pergeseran makna yang sesuai dengan kurikulum KTSP. 
(12) Menggunakan Kata yang Mengalami Pergeseran Makna

a. Pergeseran Makna Meluas dan Menyempit

1) Perluasan Makna

Makna kata ada kalanya menjadi lebih luas daripada makna semula.

Contoh:

a) Ia tinggal di rumah saudaranya.

Kata saudara dulu bermakna: 'adik/ kakak'

2) Penyempitan Makna

Makna kata ada kalanya menjadi lebih sempit daripada makna semula.

Contoh:

a) Ameliaberasal darikeluarga pendeta. Katapendeta dulu bermakna: 'ahliagama'

b. Memahami dan Menggunakan Makna Kata Peyorasi, Ameliorasi, dan Sinestesia

Perhatikan contoh kalimat-kalimat berikut ini!

1) Bini Bang Juri hamil enam bulan. (bini lebih rendah nilainya daripada istri)

2) Kambingnya beranak enam ekor. (beranak lebih rendah nilainya daripada melahirkan)

3) Pramuniaga toko ini rata-rata usianya masih belia. (pramuniaga lebih tinggi daripada pelayan toko)

4) Istrinya seorang pengusaha wanita terkemuka di kota ini. (wanita lebih tinggi nilainya daripada perempuan)

5) Senyumannya manis sekali. (indera perasa ke indera penglihatan).

6) Berita yang dibicarakan itu sebenarnya sudah basi. (indera perasa ke indera pendengar)

IX.01/I/103-105/Sem

Data (12) menunjukkan bahwa materi semantik mengenai jenis pergeseran makna dapat masuk dalam pembahasan untuk SK menulis, yaitu Mengungkapkan informasi dalam bentuk iklan baris, resensi, dan karangan pada KD Meresensi buku pengetahuan. Kegiatan meresensi adalah kegiatan menilai suatu karya dengan memaparkan kelebihan dan kekurangannya. Sehingga penggunaan kata yang mengalami pergeseran makna dalam meresensi buku kerap muncul dan digunakan untuk lebih menekankan penilaian terhadap buku tertentu. Materi jenis pergeseran makna ini dirasa sesuai dengan kurikulum dan mencerminkan tujuan atau pencapaian yang diinginkan KD tersebut.

\section{SIMPULAN}

Berdasarkan hasil analisis data dan pembahasan dihasilkan simpulan sebagai berikut. Pertama, cakupan materi tata bahasa yang terdapat pada Buku Sekolah Elektronik Bahasa Indonesia jenjang SMP/MTs terdiri atas materi fonologi, morfologi, sintaksis, dan semantik. Data materi yang diperoleh, yaitu sebanyak 164 materi dengan rincian materi fonologi sebanyak 1 materi, morfologi 110 materi, sintaksis 37 materi, dan semantik 16 materi. Materi fonologi terdapat satu cakupan materi, yaitu lafal dan diftong. Morfologi terdiri atas lima cakupan materi, yaitu afiksasi, reduplikasi, kata tugas, kelas kata, dan penggunaan kata. Sintaksis terdiri atas tiga cakupan materi, yaitu klausa, kalimat, dan fungsi SPOKPel. Semantik terdiri atas dua cakupan materi, yaitu jenis-jenis relasi makna dan perubahan serta pergeseran makna.

Kedua, model penyampaian materi tata bahasa yang digunakan pada Buku Sekolah Elektronik Bahasa Indonesia jenjang SMP/ MTs, yaitu pendekatan deduktif dan pendekatan induktif. Pendekatan deduktif digunakan pada materi fonologi, morfologi, sintaksis, dan semantik. Pendekatan induktif digunakan pada materi morfologi, sintaksis, dan semantik.

Ketiga, dalam kesesuaian materi tata bahasa dengan kurikulum KTSP, ditemukan bahwa dari 164 materi yang disajikan 88 materi telah sesuai dengan kurikulum, yaitu pada materi fonologi, morfologi, sintaksis, dan semantik yang terintegrasi pada standar kompetensi dan kompetensi dasar tertentu. Masing-masing materi telah mencerminkan tujuan pembelajaran yang terdapat pada kompetensi dasar. Terdapat pula materi yang tidak sesuai dengan kurikulum, yaitu materi tata bahasa yang tidak sesuai dengan tujuan pembelajaran yang terdapat pada kompetensi dasar.

Berdasarkan simpulan di atas, berikut disajikan saran-saran untuk lebih memantapkan penelitian selanjutnya. Pertama, bagi para guru disarankan untuk lebih selektif memilih bahan ajar yang berkaitan dengan materi tata bahasa, baik itu Buku Sekolah Elektronik (BSE) ataupun 
buku paket dan buku pegangan lainnya. Kedua, perlu adanya pemetaan tentang materi tata bahasa yang harus diajarkan oleh guru pada setiap kelas atau jenjang pendidikan. Hal ini untuk mencegah penyampaian materi yang sama dan berulang, sehingga para siswa juga tidak merasa bosan mempelajari materi tata bahasa. Ketiga, bagi para peneliti yang ingin meneliti permasalahan serupa disarankan untuk melakukan wawancara dengan para guru dan siswa untuk lebih memantapkan hasil penelitian.

\section{DAFTAR PUSTAKA}

Alwi, H., Dardjowidjojo, S., Lapoliwa, H., \& Moeljono, A.M.,. 2003. Tata Bahasa Baku Bahasa Indonesia. Jakarta: Pusat Bahasa dan Balai Pustaka. Edisi Ketiga.
Cox, Carole. 1998. Teaching Language Art: A Student and Respon Centered Classroom Third Edition. Amerika Serikat: Allyn \& Bacon.

Jick, Todd D. 1979. Mixing Qualitative and Quantitative Methods: Triangulation in Action. Cornell University, Volume 24.

Sams, Lynn. 2003. How to Teach Grammar, Analytical Thinking, and Writing: A Method that Works. English Journal, High School Edition, Volume 9 Issue 3, pp 57-65.

Yamin, Martinis. 2008. Desain Pembelajaran Berbasis Satuan Pendidikan. Jakarta: Gaung Persada Press. 